\title{
Effect of Particle Size on Properties of Sidoarjo Mud-based Geopolymer
}

\author{
Antoni $^{1 a}{ }^{1}$, David Wiyono ${ }^{2 b}$, Agie Vianthi ${ }^{1}$, \\ Permana Putra ${ }^{1}$, Gary Kartadinata ${ }^{1}$ and Djwantoro Hardjito ${ }^{1 \mathrm{c}}$ \\ ${ }^{1}$ Department of Civil Engineering, Petra Christian University, Jalan Siwalankerto 121-131, \\ Surabaya 60236, Indonesia \\ ${ }^{2}$ Postgraduate Program in Civil Engineering, Petra Christian University, Jalan Siwalankerto 121- \\ 131, Surabaya 60236, Indonesia \\ aantoni@petra.ac.id, bwiyono.david@gmail.com, 'djwantoro.h@petra.ac.id
}

Keywords: Sidoarjo mud, particle size, geopolymer, acid resistance, chloride penetration.

\begin{abstract}
The eruption of Sidoarjo mud volcano that has been taken place since 2006 had caused significant damage to the local social environment, and until now there is no immediate solution that can be offered. Utilization of the Sidoarjo mud as construction material recently has gained some advancement by calcination of the mud, that make the previously inert material to become more reactive and to be more viable for its use as cement replacement or geopolymer precursor. This paper reports an on-going study to utilize the Sidoarjo mud as precursor of geopolymer by investigating the influence of particle size on the reactivity of the calcined Sidoarjo mud. Furthermore, durability properties of Sidoarjo mud-based geopolymer was also studied. The results show that making finer the mud particles by milling in longer period, using a rod-mill drum for 8 hours, can increase the reactivity of the mud. Compressive strength of geopolymer mortar can increase up to $155 \%$ when compared to the ones based on milling time of only 2 hours. Durability properties of sulphate acid resistance and chloride penetration are comparable to fly ash-based geopolymer, while the shrinkage measurement showing higher value.
\end{abstract}

\section{Introduction}

Effort to utilize the abundant material from mud volcano eruption in Sidoarjo, East Java, Indonesia has been going on since its eruption in May 2006. The volcanic mud has covered not less than 640 hectares of fertile land. In some areas, the height of the embankment is up to $12 \mathrm{~m}$. The disaster needs to be mitigated. It has been establish that the mud having a crystalline microstructure and high shrinkage. It cannot be used as construction material in its initial condition [1]. The total content of $\mathrm{SiO}_{2}, \mathrm{Al}_{2} \mathrm{O}_{3}$ and $\mathrm{Fe}_{2} \mathrm{O}_{3}$ in Sidoarjo mud is higher than $80 \%$. This makes it possible to be used, but only after heat treatment is applied to convert its crystalline structure.

Calcination of the Sidoarjo mud was found to change it microstructures, and render it possible to be used as pozzolanic material and geopolymer precursor [2-5]. Calcination temperature at $700^{\circ} \mathrm{C}$ $900^{\circ} \mathrm{C}$ is considered enough to change its crystalline microstructure to be amorphous, and hence to make it more reactive [3]. The use of Sidoarjo mud as pozzolanic material can replace up to $60 \%$ of cement content with the Strength Activity Index (SAI) of 85\% at 28 day, and more than $90 \%$ at 56 day [5]. As a geopolymer precursor, the use of $100 \%$ calcined Sidoarjo mud as cementing material has been made possible [3-4]. However, to date no report is available on the influence of particle size of the calcined mud on the properties of geopolymer mortar. This paper reports the effect of particle size affected by milling time on the calcined Sidoarjo mud to make geopolymer mortar. The durability properties is also reported in this paper, i.e. sulphate acid resistance, chloride penetration resistance, and shrinkage of the Sidoarjo mud-based geopolymer.

\section{Experimental Program}

Materials. Sidoarjo Mud used in this study were taken directly near the centre of eruption. Sidoarjo mud should undergo several processes before it can be used as reactive material. The mud was 
formed into brick-shape for easy handling, dried in the laboratory oven at $110^{\circ} \mathrm{C}$ for 24 hours to reduce its water content (Fig. 1). Then, the bricks were transported to local roof tile manufacture kiln to be heated to peak temperature of $945^{\circ} \mathrm{C}$ for 5 hours and gradually cool to room temperature for 36 hours. It was observed that the cross section of the brick have some unevenness of the color showing that there were some un-uniformity of the calcination process. However, the calcined mud was mixed uniformly once it was ground in the milling machine. The XRF test results and the LOI content are shown in Table 1.

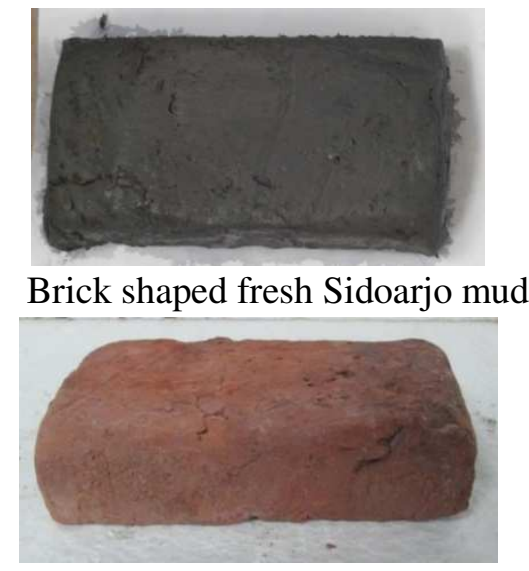

After Calcination $945^{\circ} \mathrm{C}-5 \mathrm{hrs}$

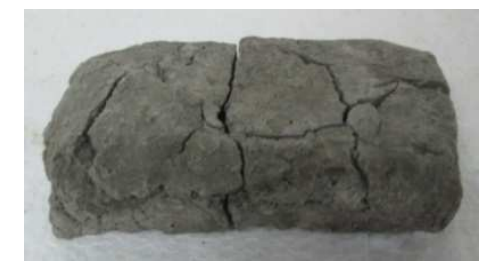

After oven dried $110^{\circ} \mathrm{C}-24 \mathrm{hrs}$

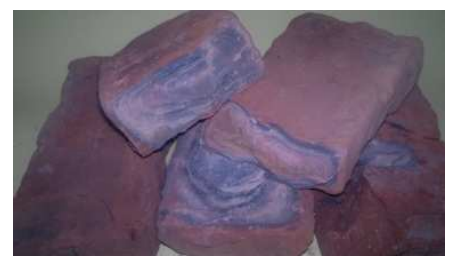

Cross section of calcined Sidoarjo mud

Fig 1: Physical Changes of Sidoarjo Mud before and after Heat Treatment

Table 1: XRF Analysis Results Sidoarjo Mud Sample (\% by mass)

\begin{tabular}{cc|cc}
\hline Oxide & Content (\%) & Oxide & Content (\%) \\
\hline $\mathrm{SiO}_{2}$ & 56.75 & $\mathrm{SO}_{3}$ & 0.96 \\
\hline $\mathrm{Al}_{2} \mathrm{O}_{3}$ & 23.31 & $\mathrm{TiO}_{2}$ & 0.38 \\
\hline $\mathrm{Fe}_{2} \mathrm{O}_{3}$ & 7.37 & $\mathrm{MnO}$ & 0.14 \\
\hline $\mathrm{CaO}$ & 2.13 & $\mathrm{Cr}_{2} \mathrm{O}_{3}$ & 0.01 \\
\hline $\mathrm{K}_{2} \mathrm{O}$ & 1.04 & $\mathrm{Na}_{2} \mathrm{O}$ & 2.7 \\
\hline $\mathrm{MgO}$ & 2.95 & $\mathrm{LOI}$ & 1.2 \\
\hline
\end{tabular}

Milling. The calcined brick of Sidoarjo mud was ground in the cylindrical steel grinding machine with rod steel bar as the grinding tools [5]. Milling was conducted for 2, 4 and 8 hours, respectively, to investigate the effect of fineness of the calcined Sidoarjo mud to its reactivity as geopolymer precursor in making geopolymer mortars. To ensure the fineness is under $63 \mu \mathrm{m}$, the powder was sieved using \#200 sieve. The particle size analysis results show that with longer grinding time the specific surface area is increased, although not in linear trend (Table 2). As the longer milling time applied, there could be some agglomeration happened on the mud particles. Even though the reactivity can be increased, but it was not detected by the measurement.

Table 2: Particle Size Analysis of Calcined Sidoarjo Mud

\begin{tabular}{ccccc}
\hline $\begin{array}{c}\text { Grinding Time } \\
\text { (hours) }\end{array}$ & $\begin{array}{c}\text { Specific Surface } \\
\text { Area }\left(\mathbf{m}^{\mathbf{2}} \mathbf{g}\right)\end{array}$ & $\begin{array}{c}\mathbf{d}(\mathbf{0 , 1}) \\
(\boldsymbol{\mu m})\end{array}$ & $\begin{array}{c}\mathbf{d}(\mathbf{0 , 5}) \\
(\boldsymbol{\mu m})\end{array}$ & $\begin{array}{c}\mathbf{d}(\mathbf{0 , 9}) \\
(\boldsymbol{\mu m})\end{array}$ \\
\hline 2 hours & 1.30 & 1.832 & 15.180 & 475.604 \\
\hline 4 hours & 2.34 & 0.937 & 7.991 & 114.402 \\
\hline 8 hours & 2.58 & 0.768 & 6.632 & 342.661 \\
\hline
\end{tabular}

Geopolymer mixtures and specimens. Sodium Hydroxide flake and Sodium Silicate solution were used as the alkaline activator. The purity of Sodium Hydroxide flake was up to $99 \%$, while the composition of Sodium Silicate were $17.14 \% \mathrm{Na}_{2} \mathrm{O}, 36.71 \% \mathrm{SiO}_{2}$, and the ratio of $\mathrm{SiO}_{2}$ and 
$\mathrm{Na}_{2} \mathrm{O}$ was 2.14 . Water to binder ratio, by mass, was kept constant at 0.3 , ratio of sand to mud was 2:1 by mass, and $\mathrm{NaOH}$ solid to Sodium Silicate solution ratio was set at 1:2, based on previous experiment. Molarity of $\mathrm{NaOH}$ solution was $10 \mathrm{M}$. The Sidoarjo mud geopolymer was cast into mortar cube sample of $5 \times 5 \times 5 \mathrm{~cm}^{3}$ size and vibrated on vibrating table to remove the entrapped air. Curing was performed in laboratory oven at $100^{\circ} \mathrm{C}$ for 24 hours. Each compressive strength data was average of 3 samples measured at 7 days testing.

Testing. The workability of fresh geopolymer mortar was measured by the flow table apparatus, while the compressive strength was measured by testing the mortar cube sample of $5 \times 5 \times 5 \mathrm{~cm}^{3}$ at 7 days. Acid resistance was measured by strength changes, by mass, after immersion in $10 \%$ sulphate acid [6], starting from day 3. Chloride penetration was measured by non-steady state migration test based on NT Build 492 [7]. Shrinkage of the specimen was determined using dial gauge set on cylindrical specimen of diameter $100 \mathrm{~mm}$ and height $200 \mathrm{~mm}$.

\section{Results and Discussion}

Influence of particle size. The variation of particle size of calcined Sidoarjo mud is indicated by the difference in milling time duration from two to eight hours. The effect of the particle size on the fresh and hardened geopolymer properties is shown in Fig. 2. Milling time of 8 hours resulted in a more workable mixture, which is consistent with the finding from the pozzolanic activity of Sidoarjo mud [5]. Most probably, finer particle is dissolved by the alkaline activator at higher rate due to having more soluble content. Compressive strength of the geopolymer mortar is showing the same trend as the one of high volume Sidoarjo mud mortar. Finer particle of the calcined Sidoarjo mud reacts faster, resulted in higher strength. Strength increase of $55 \%$ was obtained by increasing the milling time of the mud from 2 to 8 hours.
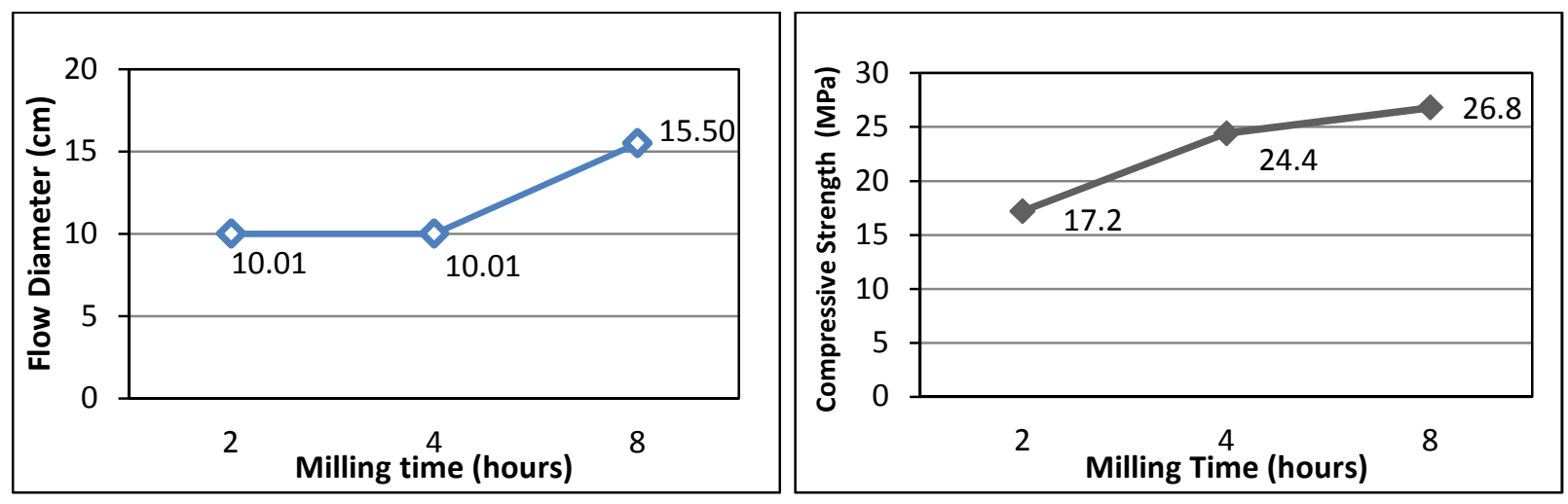

Fig. 2: Flow of the fresh geopolymer mortar and 7 days compressive strength by varying the milling time
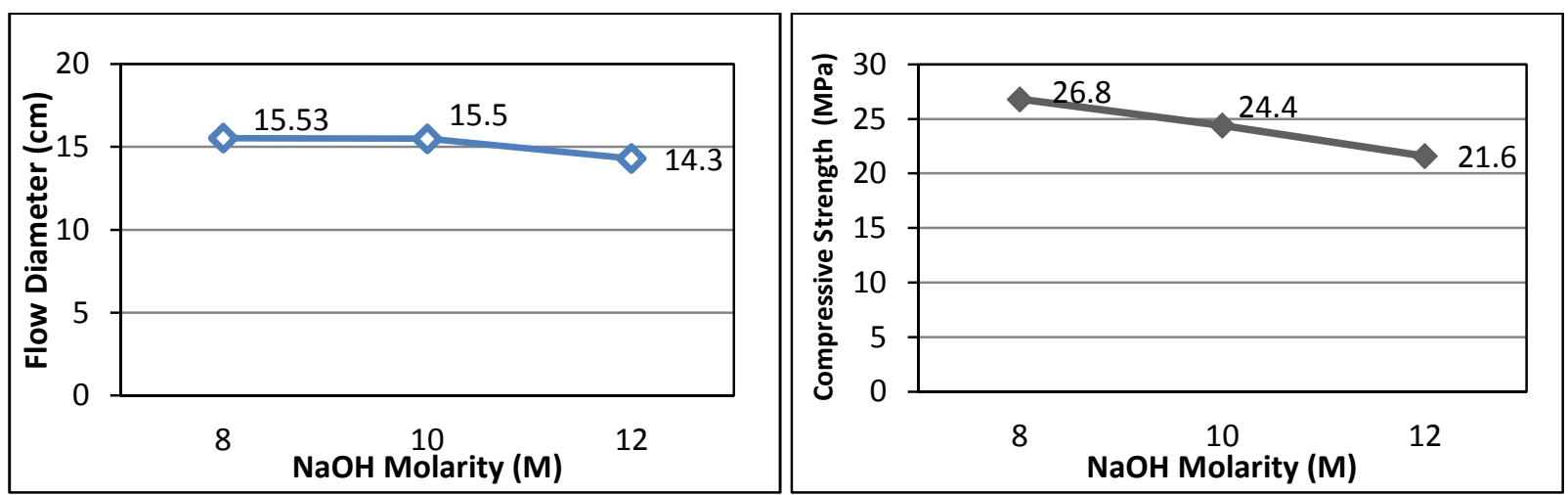

Fig. 3: Flow of the fresh geopolymer mortar and 7 days compressive strength by varying Sodium Hydroxide Molarity 
Molarity of alkaline activator. Fig. 3 shows the influence of the sodium hydroxide molarity on the fresh and hardened geopolymer mortar properties. The behavior of the fresh mortar did not vary significantly with the changes of the $\mathrm{NaOH}$ molarity. The figure also shows that there is slight reduction on the compressive strength of the geopolymer mortar with the increase of the $\mathrm{NaOH}$ molarity.

Sulphate Acid Resistance. Ten percent - by mass - of Sulfuric acid solution was used to accelerate the testing duration to measure the resistance of Sidoarjo mud-based Geopolymer to sulfuric acid attack. 8 hours grinding time of Sidoarjo mud was used. The mortar was soaked from day-3 until day-56. It was found that there was almost no change in compressive strength with the increase of time of exposure (Fig. 4). The strength loss up to 56 days is considered good when comparing to the fly ash geopolymer [6].

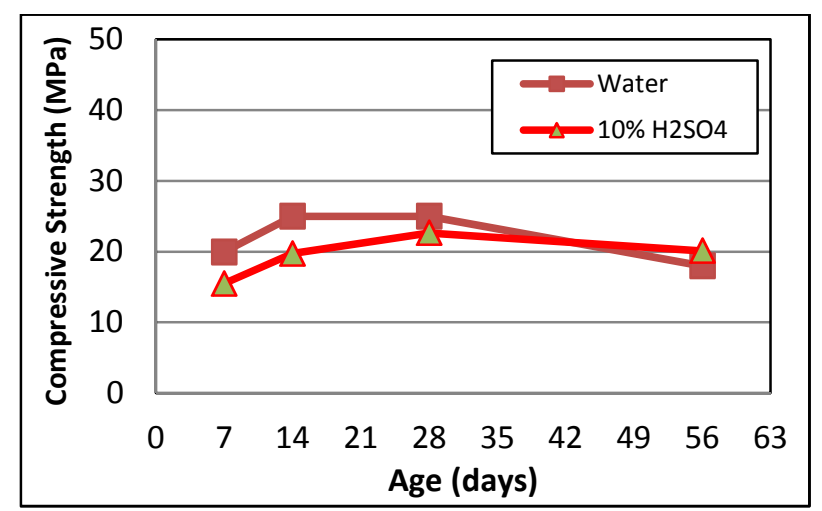

Fig. 4: Compressive strength of the Sidoarjo mud geopolymer submerged in water and suphate acid.

Chloride Ion Penetration Resistance. Chloride Ion Penetration Resistance was measured by Rapid Chloride Migration Test [7] to evaluate the permeability of the geopolymer mortar. Calcined Sidoarjo mud with 8 hours grinding time was used. The results show that the non-steady state migration coefficient $\left(D_{n s s m}\right)$ values obtained was $6.437 \times 10^{-12} \mathrm{~m}^{2} / \mathrm{s}$ (Fig. 5). This result is comparable to the previous study on geopolymer mortar made from fly ash, with a value $D_{n s s m}$ $4.849 \times 10^{-12} \mathrm{~m}^{2} / \mathrm{s}$, and also to the High Volume Fly Ash Concrete with $60 \%$ fly ash content and water to binder ratio of 0.3 that has $D_{n s s m}$ value of $14.345 \times 10^{-12} \mathrm{~m}^{2} / \mathrm{s}$ [8]. The smaller migration coefficient indicates higher resistance to penetration of chloride ions.

Shrinkage. Fig. 6 shows the measurement of the shrinkage of the geopolymer mortar measured by using a dial gauge daily until 28 days. The shrinkage is shown to occur in a faster rate during the earlier age of the mortar, especially until day 16, with the value of 675 micro strain. After that there is no significant increase of strain. The shrinkage of the Sidoarjo mud-based geopolymer mortar is larger than one of the fly ash-baed geopolymer as reported by Wallah [9]. The shrinkage of the fly ash geopolymer was measured at 100 micro strain in early age at about 20 days, and afterward did not increase again.

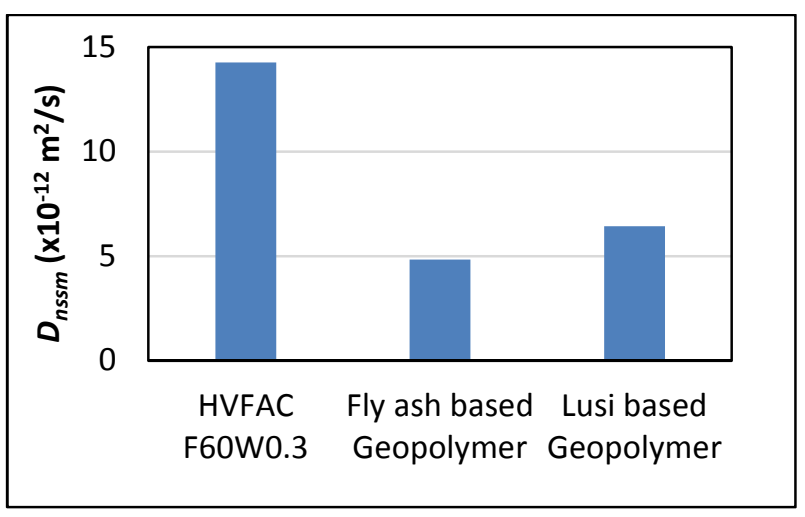

Fig.5: Diffusion Coefficient of the Geopolymer

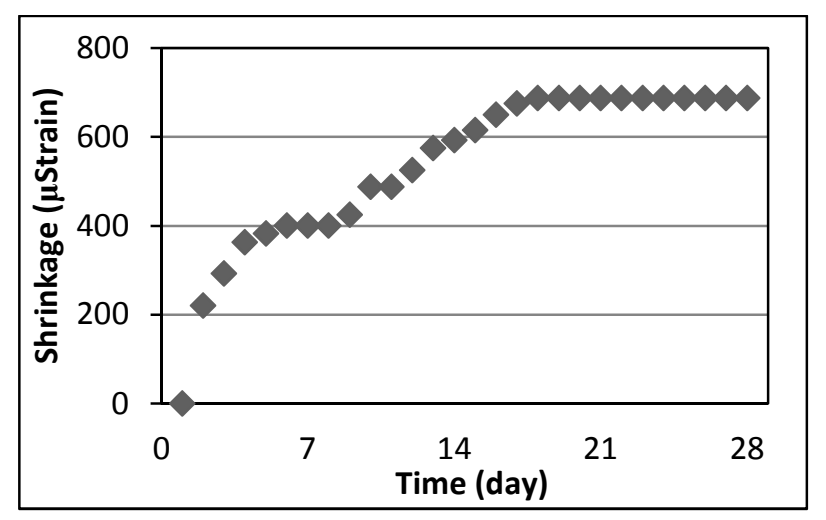

Fig. 6: Shrinkage of the Geopolymer 


\section{Conclusion}

This study investigates the effect of the particle fineness of the calcined Sidoarjo mud to be used as a geopolymer precursor. Based on the results and discussion, there are several conclusions that can be drawn, i.e.:

a. The finer particle of the calcined Sidoarjo mud has better reactivity, thus resulted in higher compressive strength of geopolymer mortar. Milling time of 8 hours with SSA of $2.58 \mathrm{~m}^{2} / \mathrm{g}$ in the rod mill resulted in an increase in compressive strength about $55 \%$, compared to the one of 2 hours milling time with SSA of $1.30 \mathrm{~m}^{2} / \mathrm{g}$.

b. The variation of sodium hydroxide molarity in between $8-12 \mathrm{M}$ does not show significant difference in the compressive strength, indicating that the use of alkaline activator can be reduced.

c. Durability properties of the Sidoarjo mud geopolymer measured by sulphate acid resistance and chloride penetration shows that it has comparable properties to fly ash-based geopolymer.

d. Shrinkage measurement of the Sidoarjo mud geopolymer shows significantly larger value compared to fly ash geopolymer. However, long term shrinkage was not observed in this study.

\section{Acknowledgements}

This work was financially supported by The Directorate General for Higher Education, Ministry of Education and Culture, Indonesia under the Decentralized Competitive Research Grant Scheme AUPT 2012, 2013 and The Centralized Competitive Research Grant HIKOM 2014.

\section{References}

[1] J. J. Ekaputri and Triwulan, "Study on Porong Mud-Based Geopolymer Concrete, Proceeding of $2^{\text {nd }}$ Asian Concrete Federation Conference, Bali, Indonesia, November 20-21, 2006.

[2] D. Hardjito, Antoni, G.M. Wibowo and D. Christianto, "Pozzolanic Activity Assessment of LUSI Mud in Semi High Volume Pozzolanic Mortar”, Materials, vol 5, pp. 1654-1660, 2012.

[3] Antoni, R. Geman, R.T. Tjondro, J. Anggono, and D. Hardjito, "Effect of Calcination Temperature of LUSI Mud on the Compressive Strength of Geopolymer Mortar", Advanced Materials Research, vol. 626, pp. 224-228, 2013.

[4] D. Hardjito, Antoni, I.V. Bunanta and K. Wicaksono. "Geopolymerization of Volcanic Mud", Proceeding of $4^{\text {th }}$ International Conference of EACEF, Singapore, June 26-28, 2013.

[5] Antoni, D. Hardjito, L. Chandra, and T. H. Widodo, "On The Development Of High Volume Volcanic Mud," Proceeding of The $13^{\text {th }}$ EASEC Conference on Structural Engineering and Construction, Sapporo, Japan, September 11-13, 2013.

[6] S. Thokchom, P. Ghosh, and S. Ghosh, "Effect of $\mathrm{Na}_{2} \mathrm{O}$ Content on Durability of Geopolymer Mortars in Sulphuric Acid," World Academy of Science, Engineering and Technology, Vol.3, pp. 508-513, 2009.

[7] Nordtest NT BUILD 492. Chloride Migration Coefficient from Non-Steady State Migration Experiment. Nordtest, Finland. 1999.

[8] Antoni, O. K. Wattimena, and D. Hardjito, "Improving Surface Durability of High Volume Fly Ash Concrete with Application of Alkali Solution," Advanced Materials Research, vol. 626, pp. 636-640, Dec. 2012.

[9] S. E. Wallah, "Drying Shrinkage of Heat-Cured Fly Ash-Based Geopolymer Concrete," Modern Applied Science, vol. 3, no. 12, pp. 14-21, 2000. 
Geopolymer and Green Technology Materials

10.4028/www.scientific.net/MSF.803

Effect of Particle Size on Properties of Sidoarjo Mud-Based Geopolymer

10.4028/www.scientific.net/MSF.803.44 